\title{
A Mid- to Long-Term Follow-Up Experience with a Specific Metal-on-Metal Total Hip Arthroplasty Design
}

\author{
Christian Carulli ${ }^{1}$ Giacomo Sani ${ }^{10}$ Fabrizio Matassi ${ }^{1}$ Roberto Civinini ${ }^{1}$ Massimo Innocenti ${ }^{1}$ \\ ${ }^{1}$ Orthopaedic Clinic, University of Florence, Florence, Italy \\ Address for correspondence Giacomo Sani, MD, Orthopaedic Clinic, \\ Joints 2019;7:91-97. \\ University of Florence, Largo Piero Palagi, Florence 50134, Italy \\ (e-mail: giacomo.sani12@gmail.com).
}

\begin{abstract}
Keywords

- metal-on-metal total hip arthroplasty

- total hip arthroplasty

- metal ion release

- hip arthritis

- proximal femoral fractures
\end{abstract}

\begin{abstract}
Purrpose Metal-on-metal (MoM) total hip arthroplasty (THA) has been a subject of recent discussion and concern due to the early failures caused by local and systemic adverse reactions related to specific designs. The aim of this study is to analyze the outcomes and survival rates of a single brand of MoM implants implanted in a consecutive series of patients at a single institution.

Methods Between 2007 and 2012, 116 (118 hips) patients were evaluated at a mean followup of 6.6 years after primary THA. The diagnosis leading to surgery was osteoarthritis (80 patients) and proximal femoral fracture (36 patients). A single design of THA was implanted. All patients were evaluated before surgery and postoperatively at 1, 3,6, and 12 months by clinical scores and radiographic studies. The data analysis was made using Student's $t$-test.

Results The minimum follow-up was of 4 years, with a mean follow-up of 6.6 years. Two aseptic loosenings of the acetabular component were recorded (one per group), which were not associated with local or systemic complications related to metal ion release. Both were revised by an isolated acetabular cup substitution with metal-onpolyethylene couplings. Nonprogressive radiolucency lines $<2 \mathrm{~mm}$ in zone 2 were observed in other six patients around the acetabular component without clinical manifestation (four in the arthritis group and two in the fracture group). Postoperative Harris Hip Score and SF-36 (36-Item Short Form Survey) score improved in both groups. Conclusion Despite several MoM implants showing early complications and failures, a specific MoM design may be associated with good clinical results at a mid- to long-term follow-up.

Level of Evidence This is a therapeutic case series, Level 4 study.
\end{abstract}

\section{Introduction}

Total hip arthroplasty (THA) represents the most successful orthopaedic procedure. Over the last decades, improvements in the surgical technique, prevention of perioperative complications, postoperative pain management, and dedicated rehabilitative protocols have produced better clinical outcomes as compared with the past. Today, THA is a fully reproducible operation with several indications not only limited to primary osteoarthritis (OA) but also to other hip alterations such as secondary OA, hip dysplasia, or fractures. ${ }^{1-4}$ Two of the most important fields of interest related to THA are the choice of the coupling and the properties of biomaterials.

"Hard" couplings such as ceramic-on-ceramic (COC) and metal-on-metal (MoM) have been enthusiastically introduced in the clinical practice for their extremely low rate of wear in terms of intra-articular particles release, as compared with the historical metal-on-polyethylene (MOP) coupling. ${ }^{5,6}$ Some concerns with MoM implants and received

November 25, 2017

accepted

April 4, 2020

published online

May 6, 2020
DOI https://doi.org/

10.1055/s-0040-1710388.

ISSN 2282-4324.

\footnotetext{
(C) 2020. The Author(s).

This is an open access article published by Thieme under the terms of the Creative Commons Attribution-NonDerivative-NonCommercial-License, permitting copying and reproduction so long as the original work is given appropriate credit. Contents may not be used for commercial purposes, or adapted, remixed, transformed or built upon. (https://creativecommons.org/ licenses/by-nc-nd/4.0/) Georg Thieme Verlag KG, Rüdigerstraße 14, 70469 Stuttgart, Germany
} 
the potential effect of metal ions on local and systemic tissues arose but without substantial evidences. ${ }^{7,8}$ On the other hand, several biomechanical advantages were correlated with MoM implants: the use of larger heads improving hip stability and range of motion; the low percentage of aseptic loosening, given the less production of polyethylene debris; and the higher hardness compared with COC implants, in which some cases of brittleness were described. ${ }^{9}$

However, the natural corrosion induced by the contact of metal bearings in the synovial fluid was thought to be correlated to an aspecific macrophage cell mediated local tissue reaction to the release of metal ions, leading to early aseptic loosening. ${ }^{10}$ Such condition was not well understood and considered until the recall of a specific implant (Articular Surface Replacement [ASR], DePuy Orthopaedics, Warsaw, Indiana, United States) in 2003. This risk was then potentially associated with all MoM implants. From that event until nowadays, there has been a perception (both from patients and surgeons) that the use of MoM implants should be discouraged because of the high probability of mechanical failure and also because of the theoretic harmful effect of metal ions in the periprosthetic tissues and systemic organs. ${ }^{11}$ Several models of the effect of the ions on joint tissues have been proposed (ALDVAL [aseptic lymphocytedominated vasculitis-associated lesion], LYDIA [lymphocytedominated immunological answer]). ${ }^{12,13}$ Moreover, cases of hypersensibility to metals have been reported in patients with MoM implants either in stable or failed implants. ${ }^{7,14}$ Simultaneously, the improvements in the manufacture of COC THAs, which are characterized by a superior hardness, a lower risk of brittleness, and advantages of an inert biomaterial, led to the increased use of such implants and a lesser consideration for MoM implants. ${ }^{15}$

Even after these events, several researches on the good outcomes and long-term survivorship of other MoM implants have been published in recent years. ${ }^{16-19}$

The aim of this study is to analyze the clinical outcomes and survival rates of a single model of MoM implants implanted in a consecutive series of patients at a single institution. The hypothesis of our study is that a single model of MoM implant used in our institute has led to good clinical outcomes and survival rates.

\section{Methods}

A total of 116 patients who consecutively underwent an MoM implant between January 2007 and March 2012 were prospectively studied. Of them, 74 were female patients and 42 male patients. The average age was 72 years (range: 63-89 years), and the mean body mass index was 25.8 (range: $23.0-$ 28.5). In 59 cases, the right hip was involved, whereas in 55 cases, the left hip was involved. In two cases, a bilateral THA was performed. The diagnosis leading to surgery was OA in 80 cases and proximal femoral fracture in the remainder 36 cases. The exclusion criteria were patients not able to give consent to procedure and to follow-up, a different diagnosis from $\mathrm{OA}$ and femoral fracture, a contralateral implant with other bearings, and a referred hypersensitivity to metals.
The study based on the principles of the Helsinki declaration was approved by the Institutional Review Board, and all patients were informed regarding treatment and follow-up. All patients underwent a radiographic study (with a standing hip X-ray in cases of patients affected by OA) and a general evaluation by geriatricians (in case of femoral fracture). Harris Hip Score (HHS) and 36-Item Short Form Survey (SF-36) were evaluated preoperatively in all patients. ${ }^{20,21}$

In 91 cases, a locoregional anesthesia was performed; in the remaining patients, a general anesthesia was performed. Two senior surgeons performed all surgeries by the same (direct lateral) approach and the same surgical technique. Two prosthetic designs belonging to the same brand (Wright Medical Technology, Memphis, Tennessee, United States) were used. In case of $\mathrm{OA}$, Conserve with cementless cup and stem was implanted, whereas, in case of femoral fracture, Collegia with pressfit cup and cemented or cementless stem was used.

All patients underwent a deep venous thromboembolism (DVT) prophylaxis with low molecular weight heparin and a short-term antibiotic prophylaxis with cefazoline $2 \mathrm{~g}$, as reported by the standard protocol of the authors' institution. A postoperative mechanical intermittent compression of the lower legs was prescribed to all patients. After a mean period of 6.9 days (range: 5-10 days), all patients were discharged and sent to rehabilitative facilities to complete the functional recovery.

Follow-up visits were performed at 1, 3, 6, and 12 months, and then at a yearly interval, with standard X-rays, HHS, SF36 , and evaluation of the positioning of the components following the criteria of DeLee and Charnley for the cups and of Gruen et al for the stems. ${ }^{22,23}$ The acetabular inclination was calculated on X-rays following specific criteria, ${ }^{24}$ and the study of the periarticular ossifications was conducted according to Brooker et al's classification. ${ }^{25}$ A data analysis was performed to compare preoperative and follow-up data using paired Student's $t$-test. Significance was set at $p<0.05$.

\section{Results}

The mean follow-up was 6.6 years (range: 4-9 years). All patients were followed up for a period of at least 4 years. Eight (7\%) patients were lost after the minimum follow-up.

No intraoperative complications were recorded. Early complications were recorded: six DVTs (four in OA patients, two in fractured patients), one superficial wound infection in an OA patient, and two cases of pneumonia (all in fractured patients). No cases of septic failure and no instability were recorded in the study population. Two aseptic loosening of cups (one in an OA patient, one in a fractured patient) were recorded 37 and 22 months postoperatively. Their inclination was 40 and 44 degrees, respectively. Both cups showed an abnormal rotation (excessive anteversion) and were thus revised by an isolated revision with jumbo cups fixed by screws and MOP couplings. In either case, no synovitis or bone alterations related to metal ions was found at histological analyses on intraoperative specimens (-Figs. 1 and 2).

The mean cup inclination in the non-failed implants was 42.9 degrees (range: $42-49$ degrees). The mean preoperative 

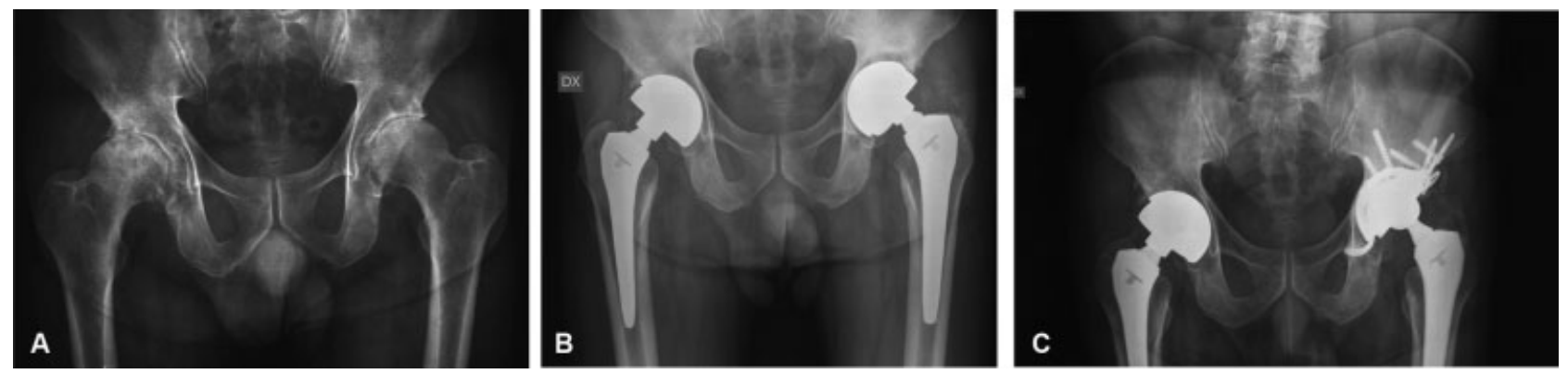

Fig. 1 (A) Bilateral hip arthritis of a 69-year-old male patient undergoing a staged cementless metal-on-metal total hip arthroplasty (THA) (one in 2008 and the other in 2009). (B) Two years after the last THA, aseptic loosening of the left acetabular cup with migration can be seen. (C) Followup at 3 years after isolated revision of the left acetabular cup (follow-up of the right hip: 6 years).
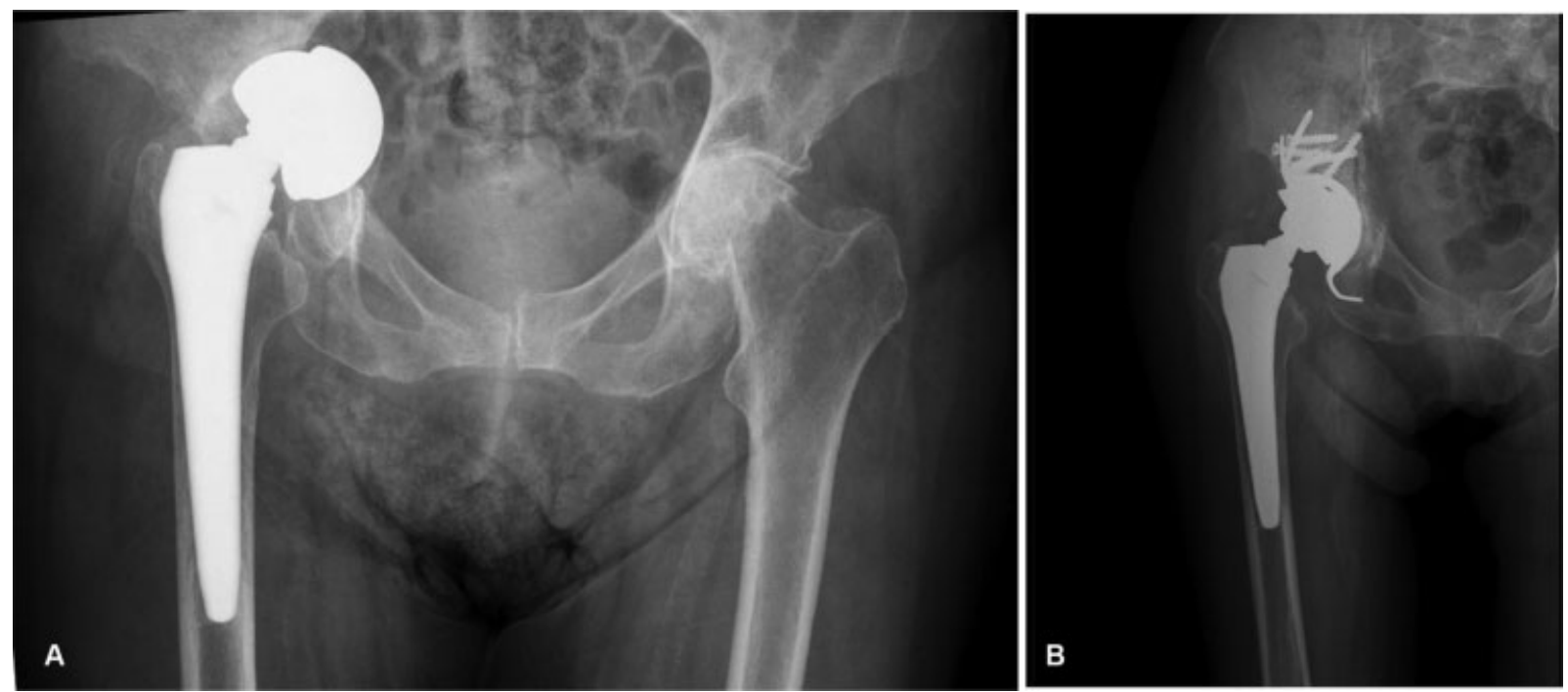

Fig. 2 A 74-year-old female patient treated with a cementless metal-on-metal total hip arthroplasty. (A) After 3 years follow-up, aseptic loosening of the acetabular cup with migration can be seen. (B) One-year follow-up after isolated revision of the cup.

value of HHS was 41.1 (range: 24-52) in the OA group, with progressive postoperative improvements up to a mean score of 88.4 (range: $28-100)$ at the latest follow-up $(p<0.05)$. In the fracture group, a mean preoperative HHS of 22 (range: 10-31) and a final mean score of 87.6 (range: 34-100) were recorded $(p<0.05)$ ( - Fig. 3 ).

Regarding the SF-36, in the OA group, the mean preoperative value was 23.7 (range: 15-40) for Physical Component Summary (PCS) and 34.5 for Mental Component Summary (MCS) (range: 23-50). At the latest follow-up, the mean value was 42.2 (range: 38-52) for PCS and 50.5 for MCS (range: 39-53) $(p<0.05)$ ( - Fig. 4). In the fracture group, the mean preoperative value was 12.7 (range: 9-18) for PCS and 33.1 for MCS (range: 30-39). At the latest follow-up, the mean value was 43.3 (range: $37-48$ ) for PCS and 49.8 for MCS (range: 46-53) $(p<0.05)$ (-Fig. 5).

Nonprogressive radiolucency lines $<2 \mathrm{~mm}$ in zone 2 , according to DeLee and Charnley, were observed in four OA patients and two fractured patients. Furthermore, no osteolysis was found at follow-up, except in the two revised cups. No significant radiolucent lines or osteolysis in all stems were found following the criteria of Gruen et al.
Finally, we found stage 2 ossifications, according to Brooker et al, in four OA patients and three fractured patients and stage 3 in other four patients (two of both groups), however, without complaints by the patients. All these patients were administered indometacin $25 \mathrm{mg}$ three times a day for 3 weeks.

\section{Discussion}

THA is a highly successful surgical procedure. The introduction of more performing materials led to great expectations in terms of wear reduction and survivorship of hip implants. Hard bearings such as COC and MoM couplings seemed to fulfil such characteristics. ${ }^{26-30}$ However, first-generation implants failed due to aseptic loosening or other mechanical issues. ${ }^{31-34}$ Particularly, the first MoM implants dramatically failed because of brittleness. ${ }^{35,36}$ Improvements in the manufacturing of materials and new designs of the MoM components were made in the third generation, which were characterized by large head diameters, increased stability, and better clearance, compared with the past. ${ }^{37,38}$

Metals in contact with biologic fluids tend to corrode, releasing metal ions locally and toward the blood flow. This 


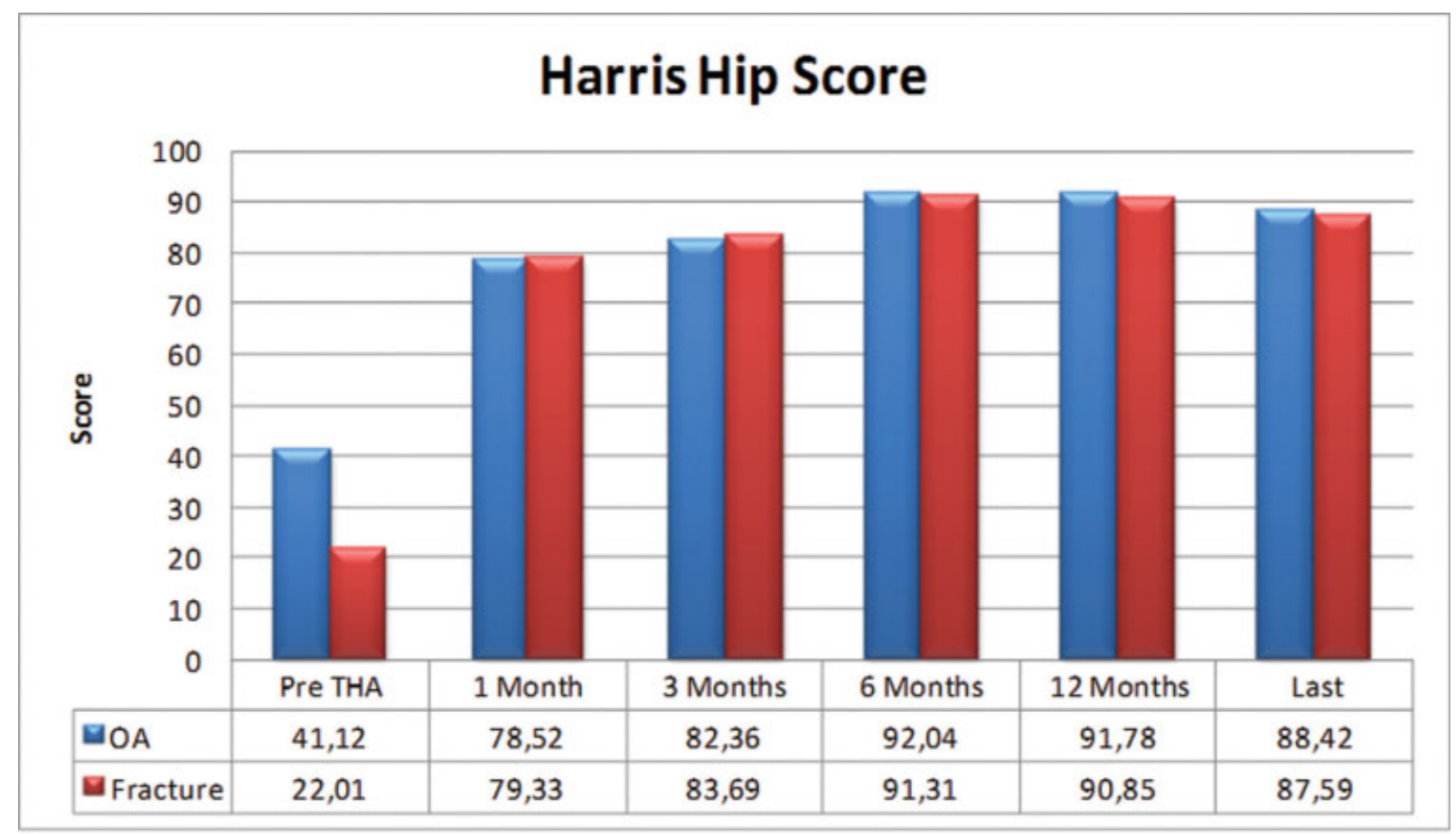

Fig. 3 Clinical assessment using the Harris Hip Score. OA, osteoarthritis; THA, total hip arthroplasty.

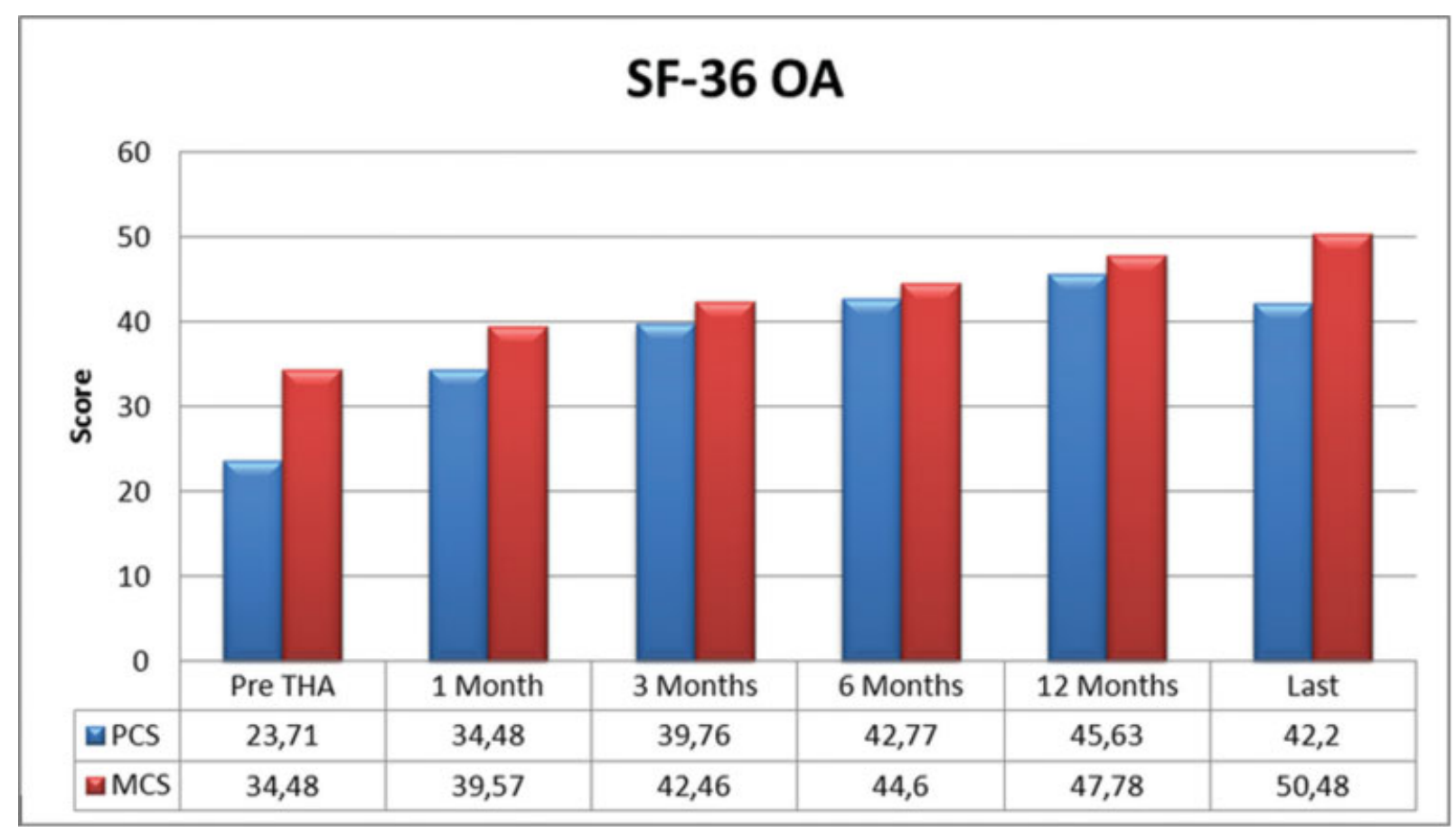

Fig. 4 SF-36 assessment in the osteoarthritis group. OA, osteoarthritis; MCS, Mental Component Summary; PCS, Physical Component Summary; SF-36, 36-Item Short Form Survey; THA, total hip arthroplasty.

remains a hot point of debate because there is a risk of hypersensitivity and potential toxic effects on specific tissue in sensitive patients. ${ }^{14,39-41}$ Until 2003, no actual reason to suspect any of these effects was strongly considered. The large number of early failures of a specific design, the ASR (DePuy Orthopaedics), first used as hip resurfacing implant and later as THA, had a worldwide high resonance. In a high percentage of cases, local bone reactions, pseudotumors, and synovitis were associated with the failure of such implants, with rates reported up to $68 \%{ }^{39,42}$ The main mechanism of failure has been related to several factors: the poor positioning of the cup, the design of the implant, and the susceptibility of patients. ${ }^{43}$ Surely, the excessive wear due to an altered release of metal ions is the main reason for the failure of ASR cups. Moreover, while a moderate-to-mild release of ions induces a local osteolysis at the bone/implant interface, 


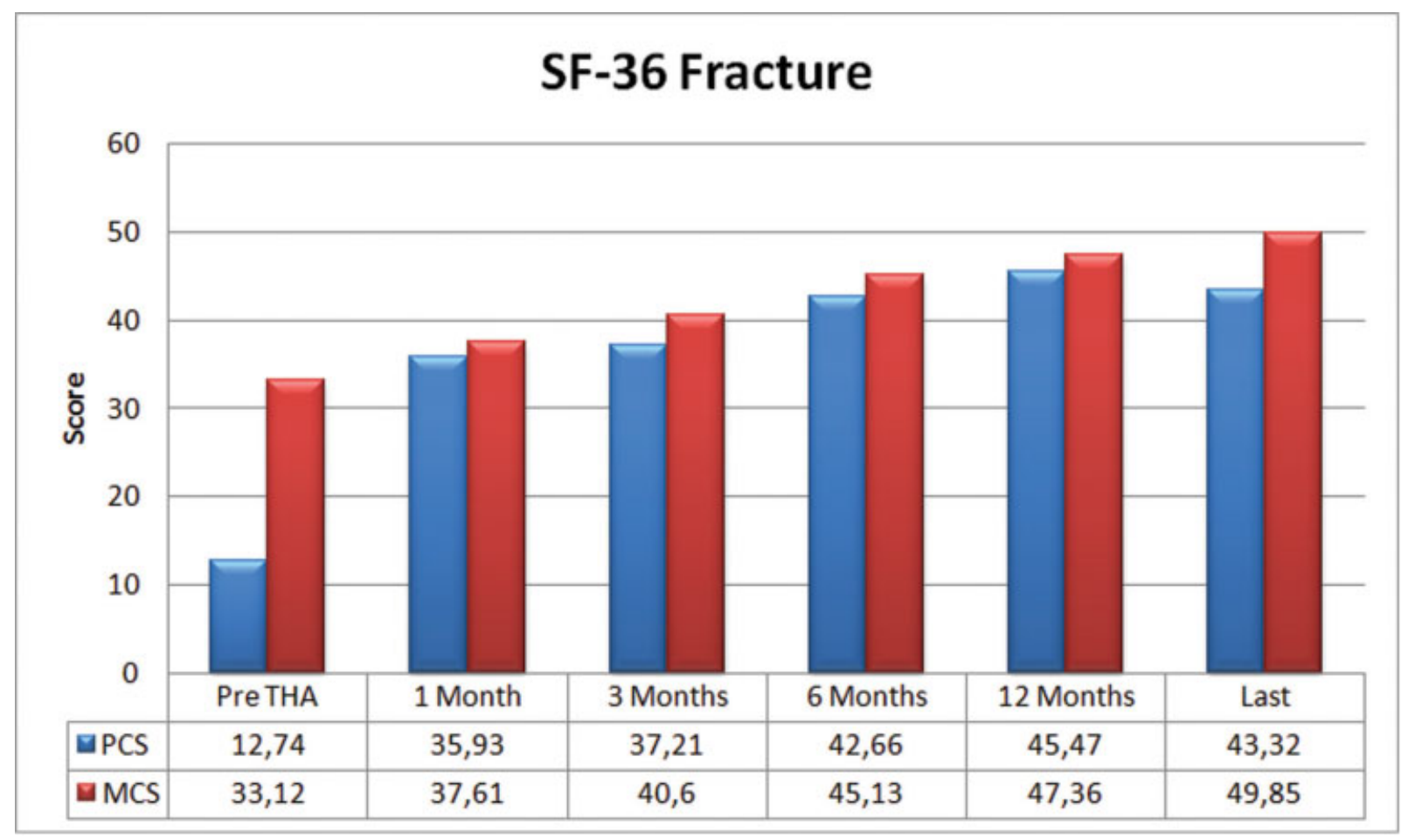

Fig. 5 SF-36 assessment in the fracture group. MCS, Mental Component Summary; PCS, Physical Component Summary; SF-36, 36-Item Short Form Survey; THA, total hip arthroplasty.

a high production of metal particles may be considered the cause of potential systemic toxicity represented by apoptosis, tissue necrosis, and genomic alterations. ${ }^{10,44,45}$ Patients with ASR presented elevated blood and urinary levels of chrome ( $\mathrm{Cr}$ ) and cobalt (Co), while patients with other types of MoM implants usually have a slight elevation of such values. ${ }^{46,47}$ However, for the latter implants, no symptoms or early failures have been addressed, as the experience reported in this series. Recently, patients with M2a acetabular MoM components (Biomet Orthopaedics, Warsaw, Indiana, United States) have shown high rates of pseudotumor at a mid-term follow-up, leading to revision in a percentage ranging from 4 to $8 \%$ and loosening in $31 \% ; 13.8 \%$ of the studied hips had a definite adverse reaction to metal debris (ARMD), and $53.8 \%$ of the studied hips had a definite, probable, or possible ARMD. ${ }^{48-50}$ Swelling, clicking, pain, and sensation of subluxation were also reported by patients with this implant. ${ }^{48}$

A strong debate revolves also around the potential hypersensitivity in patients with MoM implants. Some interesting studies revealed that well-functioning MoM implants may produce a hypersensitivity to metals, whereas loose implants show a risk ranging from 50 to $60 \%{ }^{14,51}$ Patients with MoM implants have higher values of urinary and blood concentrations of $\mathrm{CrCo}$ than other couplings. ${ }^{52,53}$ As workers exposed to metals are prone to develop malignant tumors, ${ }^{54}$ it is reasonable to consider patients with MoM implants as at high risk for cancer. However, to date, no study has highlighted such improved risk. ${ }^{55-57}$ According to the latest studies, the intrasynovial fluid concentration of $\mathrm{CrCo}$ in patients with MoM implants reflects blood concentrations of these ions. ${ }^{58,59}$ Nevertheless, despite contrasting opinions, there is no clear evidence that urinary or blood concentrations of $\mathrm{CrCo}$ ions are strictly related with the survivorship. ${ }^{60-64}$

On the other hand, MoM implants showed excellent midto long-term outcomes. ${ }^{17,65,66}$ Early revisions were substantially necessary only in ASR implants. ${ }^{67-69}$

Beyond the inner properties of MoM cups, other factors such as the proper positioning of the acetabular component, adequate components lubrication, ${ }^{70}$ and a good clearance ${ }^{71}$ are crucial for the correct functioning and long survivorship of the implant. As a matter of fact, acetabular cups inclination $>50$ degrees have been associated with poor outcomes. $^{72,73}$ In our experience, the mean inclination of approximately 43 degrees witnesses such a critical aspect in the final results.

This study has some limitations. The population is not numerically consistent. No blood or urinary samplings were harvested, and consequently no study has been performed on the hypotetic metal ion release. However, almost all patients were followed-up for a mid- to long term, and no one complained of symptoms to be related to metal hypersensitivity or other toxic effects. Thus, we did not have any need to perform laboratory assays. Furthermore, satisfactory outcomes and a midterm survivorship were reported.

In conclusion, modern MoM implants have theoretic advantages compared with other couplings. Unfortunately, some specific design has shown dramatic failures due to their abnormal metal ion release, associated with local bone alterations and theoretical systemic effects. Despite these events, most of the implanted MoM implants are well functioning up to now, however, mostly because of the refusal of this option expressed by patients. 
Conflict of Interest

None declared.

\section{References}

1 Learmonth ID, Young C, Rorabeck C. The operation of the century: total hip replacement. Lancet 2007;370(9597):1508-1519

2 Ejnisman L, Leonhardt NZ, Fernandes LF, Leonhardt MDC, Vicente JR, Croci AT. Comparison of total hip arthroplasty in osteoarthritis of mechanical and rheumatologic causes. Acta Ortop Bras 2014; 22(01):38-42

3 Pierce TP, Elmallah RK, Jauregui JJ, Verna DF, Mont MA. Outcomes of total hip arthroplasty in patients with osteonecrosis of the femoral head-a current review. Curr Rev Musculoskelet Med 2015;8(03):246-251

4 Carulli C, Felici I, Martini C, et al. Total hip arthroplasty in haemophilic patients with modern cementless implants. J Arthroplasty 2015;30(10):1757-1760

5 Knight SR, Aujla R, Biswas SP. Total hip arthroplasty - over 100 years of operative history. Orthop Rev (Pavia) 2011;3(02):e16

6 Sands D, Schemitsch EH. The role of metal-on-metal bearings in total hip arthroplasty and hip resurfacing: review article. HSS J 2017;13(01):2-6

7 Hjorth MH, Stilling M, Soballe K, et al. No association between pseudotumors, high serum metal-ion levels and metal hypersensitivity in large-head metal-on-metal total hip arthroplasty at 57-year follow-up. Skeletal Radiol 2016;45(01):115-125

8 Tharani R, Dorey FJ, Schmalzried TP. The risk of cancer following total hip or knee arthroplasty. J Bone Joint Surg Am 2001;83(05): 774-780

9 Harkess JW, Crockarell JR. Arthroplasty of the hip. In: Canale ST, Beaty JH, eds. Campbell's Operative Orthopaedics. 11th ed. St Louis, MO: CV Mosby; 2007:318-334

10 Hartmann A, Lützner J, Kirschner S, Witzleb WC, Günther KP. Do survival rate and serum ion concentrations 10 years after metalon-metal hip resurfacing provide evidence for continued use? Clin Orthop Relat Res 2012;470(11):3118-3126

11 U.S. Food and Drug Administration. Concerns about Metal-on-Metal Hip Implants. https://www.fda.gov/medical-devices/metal-metalhip-implants/concerns-about-metal-metal-hip-implants

12 Willert HG, Buchhorn GH, Fayyazi A, et al. Metal-on-metal bearings and hypersensitivity in patients with artificial hip joints. A clinical and histomorphological study. J Bone Joint Surg Am 2005; 87(01):28-36

13 Ricciardi BF, Nocon AA, Jerabek SA, et al. Histopathological characterization of corrosion product associated adverse local tissue reaction in hip implants: a study of 285 cases. BMC Clin Pathol 2016;16:3

14 Granchi D, Cenni E, Giunti A, Baldini N. Metal hypersensitivity testing in patients undergoing joint replacement: a systematic review. J Bone Joint Surg Br 2012;94(08):1126-1134

15 Yin S, Zhang D, Du H, Du H, Yin Z, Qiu Y. Is there any difference in survivorship of total hip arthroplasty with different bearing surfaces? A systematic review and network meta-analysis. Int J Clin Exp Med 2015;8(11):21871-21885

16 Engh CA Jr, Sritulanondha S, Korczak A, et al. No Difference in reoperations at 2 years between ceramic-on-metal and metal-onmetal THA: a randomized trial. Clin Orthop Relat Res 2016;474 (02):447-455

17 Engh CA Jr, Ho H, Engh CA. Metal-on-metal hip arthroplasty: does early clinical outcome justify the chance of an adverse local tissue reaction? Clin Orthop Relat Res 2010;468(02):406-412

18 Neumann DR, Thaler C, Hitzl W, Huber M, Hofstädter T, Dorn U. Long-term results of a contemporary metal-on-metal total hip arthroplasty: a 10-year follow-up study. J Arthroplasty 2010;25 (05):700-708
19 Amstutz HC, Le Duff MJ. Eleven years of experience with metalon-metal hybrid hip resurfacing: a review of 1000 conserve plus. J Arthroplasty 2008;23(06, Suppl 1):36-43

20 Nilsdotter A, Bremander A. Measures of hip function and symptoms: Harris Hip Score (HHS), Hip Disability and Osteoarthritis Outcome Score (HOOS), Oxford Hip Score (OHS), Lequesne Index of Severity for Osteoarthritis of the Hip (LISOH), and American Academy of Orthopedic Surgeons (AAOS) Hip and Knee Questionnaire. Arthritis Care Res (Hoboken) 2011;63:200-207

21 Kelly A, Rush J, Shafonsky E, et al. Detecting short-term change and variation in health-related quality of life: within- and between-person factor structure of the SF-36 health survey. Health Qual Life Outcomes 2015;13:199

22 DeLee JG, Charnley J. Radiological demarcation of cemented sockets in total hip replacement. Clin Orthop Relat Res 1976; (121):20-32

23 Gruen TA, McNeice GM, Amstutz HC. "Modes of failure" of cemented stem-type femoral components: a radiographic analysis of loosening. Clin Orthop Relat Res 1979;(141):17-27

24 Ackland MK, Bourne WB, Uhthoff HK. Anteversion of the acetabular cup. Measurement of angle after total hip replacement. J Bone Joint Surg Br 1986;68(03):409-413

25 Brooker AF, Bowerman JW, Robinson RA, Riley LH Jr. Ectopic ossification following total hip replacement. Incidence and a method of classification. J Bone Joint Surg Am 1973;55(08): $1629-1632$

26 Sentürk U, Perka C. Ceramic-on-ceramic bearings in total hip arthroplasty (THA) [in German]. Z Orthop Unfall 2015;153(02): 198-202

27 Pezzotti G, Yamamoto K. Artificial hip joints: the biomaterials challenge. J Mech Behav Biomed Mater 2014;31:3-20

28 Silverman EJ, Ashley B, Sheth NP. Metal-on-metal total hip arthroplasty: is there still a role in 2016? Curr Rev Musculoskelet Med 2016;9(01):93-96

29 Rieker C, Konrad R, Schön R. In vitro comparison of the two hardhard articulations for total hip replacements. Proc Inst Mech Eng H 2001;215(02):153-160

30 Hannouche D, Zaoui A, Zadegan F, Sedel L, Nizard R. Thirty years of experience with alumina-on-alumina bearings in total hip arthroplasty. Int Orthop 2011;35(02):207-213

31 Thomas MS, Wimhurst JA, Nolan JF, Toms AP. Imaging metal-onmetal hip replacements: the Norwich experience. HSS J 2013;9 (03):247-256

32 Walker PS, Salvati E, Hotzler RK. The wear on removed McKeeFarrar total hip prostheses. J Bone Joint Surg Am 1974;56(01): 92-100

33 Yoon TR, Rowe SM, Jung ST, Seon KJ, Maloney WJ. Osteolysis in association with a total hip arthroplasty with ceramic bearing surfaces. J Bone Joint Surg Am 1998;80(10):1459-1468

34 Cousen PJ, Gawkrodger DJ. Metal allergy and second-generation metal-on-metal arthroplasties. Contact Dermat 2012;66(02): 55-62

35 August AC, Aldam CH, Pynsent PB. The McKee-Farrar hip arthroplasty. A long-term study.J Bone Joint Surg Br 1986;68(04):520-527

36 Dobbs HS. Survivorship of total hip replacements. J Bone Joint Surg Br 1980;62-B(02):168-173

37 Cuckler JM, Moore KD, Lombardi AV Jr, McPherson E, Emerson R. Large versus small femoral heads in metal-on-metal total hip arthroplasty. J Arthroplasty 2004;19(08, Suppl 3):41-44

38 Triclot P. Metal-on-metal: history, state of the art (2010). Int Orthop 2011;35(02):201-206

39 Matthies AK, Skinner JA, Osmani H, Henckel J, Hart AJ. Pseudotumors are common in well-positioned low-wearing metal-onmetal hips. Clin Orthop Relat Res 2012;470(07):1895-1906

40 Cohen D. How safe are metal-on-metal hip implants? BMJ 2012; 344:e1410 
41 Innocenti M, Carulli C, Matassi F, Carossino AM, Brandi ML, Civinini R. Total knee arthroplasty in patients with hypersensitivity to metals. Int Orthop 2014;38(02):329-333

42 Dramis A, Clatworthy E, Jones SA, John A. High failure rate of the R3 metal-on-metal total hip arthroplasty. Hip Int 2014;24(05): 442-447

43 Dhotare SV, Shivarathre DG, Croitoru C, Armstrong C, Kapoor B, Peter VK. Medium-term results following large diameter metalon-metal total hip arthroplasty: increasing failure after 6 years. Hip Int 2016;26(03):226-232

44 Catelas I, Campbell PA, Dorey F, Frausto A, Mills BG, Amstutz HC. Semi-quantitative analysis of cytokines in MM THR tissues and their relationship to metal particles. Biomaterials 2003;24(26): 4785-4797

45 Mahendra G, Pandit H, Kliskey K, Murray D, Gill HS, Athanasou N. Necrotic and inflammatory changes in metal-on-metal resurfacing hip arthroplasties. Acta Orthop 2009;80(06):653-659

46 Hug KT, Watters TS, Vail TP, Bolognesi MP. The withdrawn ASR ${ }^{\mathrm{TM}}$ THA and hip resurfacing systems: how have our patients fared over 1 to 6 years? Clin Orthop Relat Res 2013;471(02):430-438

47 Hutt J, Lavigne M, Lungu E, Belzile E, Morin F, Vendittoli PA. Comparison of whole-blood metal ion levels among four types of large-head, metal-on-metal total hip arthroplasty implants: a concise follow-up, at five years, of a previous report. J Bone Joint Surg Am 2016;98(04):257-266

48 Mokka J, Junnila M, Seppänen $M$, et al. Adverse reaction to metal debris after ReCap-M2A-Magnum large-diameter-head metalon-metal total hip arthroplasty. Acta Orthop 2013;84(06): 549-554

49 Koper MC, Mathijssen NM, Vehmeijer SB. A 5-year survival analysis of 160 Biomet Magnum M2 metal-on-metal total hip prostheses. Hip Int 2016;26(01):50-56

50 Lombardi AV Jr, Berend KR, Morris MJ, Adams JB, Sneller MA. Large-diameter metal-on-metal total hip arthroplasty: dislocation infrequent but survivorship poor. Clin Orthop Relat Res 2015; 473(02):509-520

51 Hart AJ, Sabah SA, Bandi AS, et al. Sensitivity and specificity of blood cobalt and chromium metal ions for predicting failure of metal-on-metal hip replacement. J Bone Joint Surg Br 2011;93 (10):1308-1313

52 Brodner W, Bitzan P, Meisinger V, Kaider A, Gottsauner-Wolf F, Kotz R. Serum cobalt levels after metal-on-metal total hip arthroplasty. J Bone Joint Surg Am 2003;85(11):2168-2173

53 Dahlstrand H, Stark A, Anissian L, Hailer NP. Elevated serum concentrations of cobalt, chromium, nickel, and manganese after metal-on-metal alloarthroplasty of the hip: a prospective randomized study. J Arthroplasty 2009;24(06):837-845

54 Moulin JJ, Wild P, Romazini S, et al. Lung cancer risk in hard-metal workers. Am J Epidemiol 1998;148(03):241-248

55 Corradi M, Daniel J, Ziaee H, Alinovi R, Mutti A, McMinn DJ. Early markers of nephrotoxicity in patients with metal-on-metal hip arthroplasty. Clin Orthop Relat Res 2011;469(06):1651-1659

56 Grübl A, Marker M, Brodner W, et al. Long-term follow-up of metal-on-metal total hip replacement. J Orthop Res 2007;25(07): $841-848$
57 Daniel J, Ziaee H, Pradhan C, Pynsent PB, McMinn DJ. Renal clearance of cobalt in relation to the use of metal-on-metal bearings in hip arthroplasty. J Bone Joint Surg Am 2010;92(04): 840-845

58 Beraudi A, Catalani S, Montesi M, et al. Detection of cobalt in synovial fluid from metal-on-metal hip prosthesis: correlation with the ion haematic level. Biomarkers 2013;18(08):699-705

59 De Pasquale D, Stea S, Squarzoni S, et al. Metal-on-metal hip prostheses: correlation between debris in the synovial fluid and levels of cobalt and chromium ions in the bloodstream. Int Orthop 2014;38(03):469-475

60 Migaud H, Putman S, Combes A, et al. Metal-on-metal bearing: is this the end of the line? We do not think so. HSS J 2012;8(03):262-269

61 Reito A, Parkkinen J, Puolakka T, Pajamäki J, Eskelinen A. Diagnostic utility of joint fluid metal ion measurement for histopathological findings in metal-on-metal hip replacements. BMC Musculoskelet Disord 2015;16:393

62 Hart AJ, Sabah SA, Sampson B, et al. Surveillance of patients with metal-on-metal hip resurfacing and total hip prostheses: a prospective cohort study to investigate the relationship between blood metal ion levels and implant failure. J Bone Joint Surg Am 2014;96(13):1091-1099

63 Hjorth MH, Søballe K, Jakobsen SS, Lorenzen ND, Mechlenburg I, Stilling M. No association between serum metal ions and implant fixation in large-head metal-on-metal total hip arthroplasty. Acta Orthop 2014;85(04):355-362

64 Bayley N, Khan H, Grosso P, et al. What are the predictors and prevalence of pseudotumor and elevated metal ions after largediameter metal-on-metal THA? Clin Orthop Relat Res 2015;473 (02):477-484

65 Amstutz HC, Le Duff MJ. Eleven years of experience with metalon-metal hybrid hip resurfacing: a review of 1000 conserve plus. J Arthroplasty 2008;23(06, Suppl 1):36-43

66 Koper MC, Mathijssen NM, Vehmeijer SB. A 5-year survival analysis of 160 Biomet Magnum M2 metal-on-metal total hip prostheses. Hip Int 2016;26(01):50-56

67 Langton DJ, Jameson SS, Joyce TJ, et al. Accelerating failure rate of the ASR total hip replacement. J Bone Joint Surg Br 2011;93(08): 1011-1016

68 Wienroth M, McCormack P, Joyce TJ. Precaution, governance and the failure of medical implants: the ASR((TM)) hip in the UK. Life Sci Soc Policy 2014;10:19

69 National Joint Registry for England and Wales (NJR EnglandWales) 6th Annual Report 2009. ISSN 1753-9374

70 Gill HS, Grammatopoulos G, Adshead S, Tsialogiannis E, Tsiridis E. Molecular and immune toxicity of $\mathrm{CoCr}$ nanoparticles in MoM hip arthroplasty. Trends Mol Med 2012;18(03):145-155

71 Schey JA. Systems views of optimizing metal on metal bearings. Clin Orthop Relat Res 1996;(329):115-127

72 Nicolli A, Bisinella G, Padovani G, Vitella A, Chiara F, Trevisan A. Predictivity and fate of metal ion release from metal-on-metal total hip prostheses. J Arthroplasty 2014;29(09):1763-1767

73 Campbell P, Beaulé PE, Ebramzadeh E, et al. The John Charnley Award: a study of implant failure in metal-on-metal surface arthroplasties. Clin Orthop Relat Res 2006;453(453):35-46 